\title{
Země jako kosmické těleso v předsókratovské kosmologii'
}

\author{
Radim Kočandrle \\ Fakulta filozofická Západočeské univerzity v Plzni \\ rkocandr@kfi.zcu.cz
}

\begin{abstract}
Abstrakt:
Interpretace Země v iónských archaických kosmologiích obvykle pracují s představou ploché desky ležící na vodě nebo vzduchu. Země je v nich zároveň pojímána jako konkrétní těleso umístěné v prostoru univerza. Vzhledem k meteorologické povaze iónských archaických kosmologií se však lze domnívat, že tyto kosmologie obecně nepředpokládaly prostor pod Zemí. Země tak tvořila spodní dimenzi celého univerza, přičemž nebyla považována za kosmické těleso. K zásadní změně došlo až v kosmologii italské větve filosofie, která pojala Zemi i univerzum ve tvaru sféry - tím se Země stala samostatným tělesem. Pokud však ještě předtím zprávy o Anaximandrově iónské kosmologii popisují válcovitou Zemi umístěnou uprostřed kruhů nebeských těles, lze soudit, že to byl právě Anaximandros, kdo jako první pokládal Zemi za kosmické těleso.
\end{abstract}

Klíčová slova: Anaximandros, kosmologie, meteorologie, Parmenidés, Země DOI: https://doi.org/10.46854/fc.2020.5r.659

Současné interpretace Země v iónských archaických kosmologiích obvykle pracují s představou ploché desky spočívající na vodě či vzduchu. Zároveň je takto vysvětlena i stabilita Země v univerzu. Důvody pro podobný výklad se přitom zakládají na dostupných doxografických svědectvích a jsou ve shodě se zprávami nejdůležitějšího z pramenů: Aristotela.

Implicitním východiskem takových interpretací je předpoklad, že Země je konkrétním hmotným tělesem nalézajícím se v prostoru univerza. $\mathrm{V}$ této studii se na pojetí Země u iónských archaických myslitelů zaměříme, přičemž však poukážeme na to, že tento zdánlivě samozřejmý předpoklad není ani zdaleka oprávněný. Jak jsme totiž upozornili na jiném místě, iónské archaické kosmologie vůbec neuvažovaly prostor pod Zemí. Země tak ztělesňovala

1 Studie je součástí grantového projektu GA ČR 19-05575S. 
spodní dimenzi celého světa, a nikoli konkrétní těleso. ${ }^{2}$ Nyní na uvedené závěry úzce navážeme, přičemž se pokusíme ukázat, kdy byla Země v předsókratovské kosmologii poprvé pojata jako samostatné kosmické těleso.

\section{Země iónských archaických myslitelů}

V obecném povědomí jsou iónské archaické kosmologie, tedy de facto nejstarší předsókratovské kosmologické koncepce, v prvé řadě neodmyslitelně spjaty s plochou Zemí. ${ }^{3}$ Nicméně tato představa může být významně oslabena dochovanou textovou evidencí. Zaměříme-li se nejprve právě na doložené popisy Země, shledáme, že jsou velmi stručné. Nejčastěji přitom vycházejí z kontextu jejího nehybného umístění v univerzu. Ohledně konkrétního tvaru Země se pak obvykle objevují pouze zmínky o její plochosti nebo - možná překvapivě - naopak kulatosti. Spolu s tím nacházíme rovněž obecné uvedení Země jako takové, bez jakýchkoli přívlastků.

V prípadě Thaléta se lze domnívat, že prvoplánový dojem Země jako ploché desky patrně nejvíce evokuje Aristotelova zpráva, podle níž měl Thalés soudit, že Země plave na vodě. Na daném místě spisu $O$ nebi se Aristotelés zabývá zdůvodněním nehybnosti Země, které nalezl u svých předchůdců. Za nejstarší zdůvodnění označuje právě schopnost Země plavat na vodě, které spojuje s Thalétem. $Z$ Aristotelova opatrného vyjádření je ovšem zároveň zřejmé, že sám byl ohledně Mílétana odkázán na nepřímé zdroje: „Jiní však tvrdí, že [Země] spočívá na vodě. Takový je totiž nejstarší výklad, podle něhož prý Thalés z Mílétu tvrdí, že [Země] setrvává [v klidu], nebot' plave, jako plave dřevo nebo něco podobného. Žádná z takových věcí totiž přirozeně nespočívá na vzduchu, nýbrž na vodě, - takže není stejné vysvětlení ohledně Země a vody, která Zemi nese. Ze své přirozenosti totiž nesetrvává nahoře, ale spočívá na něčem." ${ }^{* 4}$

Motiv Země ležící na vodě se objevuje znovu v Metafyzice jako doklad Aristotelovy představy, že Thalés měl pokládat vodu za princip všeho. ${ }^{5}$ Navíc je doložen i u řady dalších referujících autorů. ${ }^{6}$ Lze si ovšem povšimnout, že

2 Srov. Kočandrle, R., Prostor pod Zemí v iónských archaických kosmologiích. Filosofický časopis, 67, 2019, č. 5, s. 767-785.

3 Srov. Couprie, D. L., The Paths of the Celestial Bodies According to Anaximenes. Hyperboreus, 21, 2015, s. 10; Graham, D. W., Science Before Socrates. Parmenides, Anaxagoras, and the New Astronomy. Oxford-New York, Oxford University Press 2013, s. 79.

4 Aristotelés, De caelo II,13,294a28 = Diels, H. - Kranz, W., Die Fragmente der Vorsokratiker. Griechisch und Deutsch. Bd. I. Berlin, Weidmann 1951-1952 (dále jen: DK) 11 A 14. Neníli uvedeno jinak, překlady antických autorů pořídil na základě starších překladů V. Hladký a kol.

5 Aristotelés, Metaphysica 1,3,983b17 = DK 11 A 12.

6 Např. Simplikios, In Aristotelis Physicorum libros commentaria (dále jen: In Arist. Phys.) 23,27 = DK 11 A 13. 
Aristotelova reference ve skutečnosti nevychází z plochého tvaru Země, nýbrž se zakládá na schopnosti Země plavat. Sám Aristotelés zaměřuje následnou kritiku daného pojetí v prvé řadě na to, že ani voda nezůstává přirozeně ve vzduchu, ale musí na něčem spočívat. Zároveň se podivuje nad tím, jak je možné, aby lehčí prvek byl níže, než je prvek těžší. ${ }^{7}$ Je tak očividné, že ve výkladu nehraje roli případný tvar Země, ale naopak její povaha. Přesto mohla být plochost Země v argumentu implicitně míněna.

Patricia F. O'Gradyová nicméně upozornila, že Thalés mohl původně hovořit jen o částech Země nalézajících se na vodě, prričemž je Aristotelés zaměnil za celou Zemi. Motiv Země plovoucí na vodě by přitom vycházel z tzv. plovoucích ostrovů, o nichž se zmiňují antičtí autoři. Hérodotos ${ }^{8} \mathrm{v}$ tomto smyslu např́iklad referuje o plovoucím ostrovu Chemmis v Egyptě. ${ }^{9}$

Předpoklad Země jako objektu ležícího na vodě však nalezl oporu též v textech různých autorů, kteří pojednávají o údajném Thalétově vysvětlení důvodu zemětřesení: „Thalétův názor je nepř́ípadný. Říká, že okrsek zemský je nesen a vezen vodou jako lod'ka, a když ŕíkáme, že se chvěje [zemětřesením], tehdy se zmítá na rozbouřených vlnách; není tedy divu, že je natolik vlhká, až z ní vyvěrají řeky, když je celá ve vodě.“10

Seneca užívá obraz lodi opakovaně. Ten se navíc následně objevuje i u autorů křestanské éry. ${ }^{11}$ Ačkoli bývají analogie ke konkrétnímu předmětu v iónské archaické filosofii obvykle pokládány za signál originality textu, zde se o podobný prípad nejedná. Obecně je totiž hodnota textů popisujících zemětřesení sporná. Dobře však poukazují na postupný vývoj motivu Země umístěné na vodě v pracích pozdních autorů. ${ }^{12}$

Ačkoli se výše uvedená Aristotelova reference ve skutečnosti nevyslovuje k případnému tvaru Země, lze soudit, že právě na jejím základě byla Thalétova Země následně obvykle vnímána ve smyslu ploché desky. Ve skutečnosti ale neexistuje žádný explicitní doklad, který by plochý tvar Země potvrzoval. ${ }^{13}$

Dochované texty týkající se tvaru Země u Thaléta naopak referují o tom, že měl pokládat Zemi za kulovitou. Áetios v tomto smyslu spojuje Thaléta

7 Aristotelés, De caelo II,13,294a33-294b3.

8 Hérodotos, Historiae II, 156.

9 Srov. O'Grady, P. F., Thales of Miletus. The Beginnings of Western Science and Philosophy. Farnham-Burlington, Ashgate 2002, s. 87-94.

10 Seneca, Naturales quaestiones (dále jen: Natur. quaest.) III, 14 = DK 11 A 15.

11 Albert Veliký, Meteora III, 2,5 = G. Wöhrle (Hrsg.), Die Milesier: Anaximander und Anaximenes. Berlin-Boston, Walter de Gruyter 2012 (dále jen: TP) 1 Th 555; Vilém z Conches, Dragmaticon philosophiae $\mathrm{VI}, 2,1=$ TP 1 Th 526 .

12 Srov. Dancy, R. M., Thales, Anaximander, and Infinity. Apeiron, 22, 1989, No. 3, s. 153.

13 Srov. O'Grady, P. F., Thales of Miletus. The Beginnings of Western Science and Philosophy, c.d., s. 95. 
dokonce až se stoiky: „O tvaru Země: Thalés, stoikové a jejich následovníci [tvrdí, že] Země je kulovitá."14

Daná pasáž je ovšem doložena pouze prostřednictvím Pseudo-Plútarchovy verze Áetia a jejích opisů u Eusebia, Pseudo-Galéna ${ }^{15}$ i v arabském překladu. ${ }^{16}$ Přesto je pozoruhodné, že textová evidence týkající se tvaru Země je protikladná nejen obvyklým náhledům na Thaléta, nýbrž i na iónské archaické kosmologie jako takové.

Musíme ovšem vzít v úvahu, že výše uvedená Aristotelova reference pochází z části spisu $O$ nebi, která se netýká tvaru, nýbrž pohybu a klidu Země v univerzu. Přihlédneme-li proto k místu, které se tvaru Země explicitně věnuje, shledáme, že Aristotelés nejprve neuvádí žádná jména, nýbrž obecně tvrdí: „Jedni se domnívají, že [Země] má tvar koule, druzí, že je plochá a má tvar podobný bubnu. ${ }^{\text {17 }}$

Následně se zmínka o tvaru Země objevuje až v souvislosti s plochou Zemí v př́padě Anaximena, Anaxagory a Démokrita. ${ }^{18}$ Patricia F. O'Gradyová se tak domnívala, že pokud Anaximandros zastával pojetí Země tvaru bubnu, mohl by odkaz k těm, kdo pokládali Zemi za kulovitou, směřovat právě k Thalétovi. ${ }^{19}$

Na základě Aristotelových opatrných vyjádření je ale očividné, že neměl k dispozici žádný Mílétanův text a sám se odvolával pouze na zprávy z doslechu. Ostatně o autorství Thalétova spisu panovala nejistota již v antice. Obraz Thalétovy kosmologie tak bude nejspíše pouze poplatný až pozdním výkladům. Navzdory textové evidenci se proto lze domnívat, že se i v případě kulového tvaru Země jedná o omyl. ${ }^{20}$

Pokud u Thaléta texty nepotvrzují běžný předpoklad ploché Země, v obdobné situaci se nalézáme rovněž u Anaximandra. K jeho koncepci nicméně přihlédneme až následně. Porozhlédneme-li se naopak v textové pozůstalosti jeho údajného „nástupce“ Anaximena, vidíme, že teprve u něho máme zachovány zprávy předkládající obvyklý obraz ploché Země spočívající na fyzické opoře.

Podobně jako v př́padě Thaléta se i Anaximenovo jméno objevuje až v pasáži, týkající se nehybnosti Země v univerzu. Pokud však Aristotelés předtím v případě Thaléta akcentoval konkrétní fyzickou oporu Země v podobě vody,

14 Áetios, Plac. III,10,1 = TP 1 Th 161.

15 Eusebios, Praeparatio evangelica 15,56,1 = TP1 Th 279; Pseudo-Galénos, Hist. phil. 82,1-3 = TP 1 Th 402.

16 Qusțā ibn Lūqā, Placita philosophorum III,10,1 = TP 1 Th 490.

17 Aristotelés, De caelo, II,13,293b34-294a1. Přeložil autor.

18 Tamtéž, II,13,294b14-15.

19 Srov. O‘Grady, P. F., Thales of Miletus. The Beginnings of Western Science and Philosophy, c.d., s. 95-100.

20 Srov. Couprie, D. L., Heaven and Earth in Ancient Greek Cosmology. From Thales to Heraclides Ponticus. New York, Springer 2011, s. 65-67; s. 105. 
přičemž nebyl zmíněn žádný tvar Země, u Anaximena je tomu zcela jinak. Plochý tvar Země je totiž naopak výslovně uveden jako podmínka její stability v univerzu: „Anaximenés, Anaxagorás a Démokritos však tvrdí, že příčinou toho, že Země stojí, je její plochost. Nerazí si cestu vzduchem pod sebou, ale přikrývá jej jako poklice, což plochá tělesa zjevně dělají. Ta jsou totiž vůči větru nehybná díky protitlaku. Tvrdí, že takto to činí i Země svou plochostí vůči vzduchu pod ní. Vzduch nemá dostatečné místo, aby se pohnul, zůstává dole a v klidu, jako voda v klepsydře.“21

Plochost Země se následně uplatňuje jako důvod její stability i u dalších autorů, jakým je například Pseudo-Plútarchos: „Říká, že kontrakcí vzduchu vznikla nejprve velmi plochá Země. Proto také dává smysl, že je nadnášena vzduchem." ${ }^{22}$

V podobné dikci se nese i Hippoly tovo vyjádření: „Země je plochá a vznáší se na vzduchu. “23

Áetios pak přináší konkrétní analogii, když Zemi připodobňuje ke stolu. Vzhledem $\mathrm{k}$ ostatním popisům se přitom můžeme domnívat, že míněna je právě horní plochá deska stolu: „Podle Anaximena má Země podobu stolu.“24

Z uvedených textů je evidentní, že obvyklou představu o Zemi jako ploché desce v předsókratovské kosmologii splňuje jako první de facto až Anaximenés.

Zatímco u Anaximena jsme hned z několika pramenů informováni o jeho pojetí Země, u Hérakleita tomu tak není. Není dochován žádný text, který by přibližoval některou $\mathrm{z}$ charakteristik Země, o níž bychom si tak mohli učinit alespoň rámcový obraz. Ačkoli se z textů dozvídáme mnohé o dění v univerzu, jeho konkrétní struktura není dobře zachycena.

V případě Xenofana máme naopak doloženo hned několik pasáží, které se týkají jeho pojetí Země. Žádná z nich však nepřináší poznatky o jejím tvaru. Spíše se zaměřují na umístění Země v univerzu. Právě v tomto smyslu Xenofana vyložil Aristotelés, který jej dokonce explicitně uvádí jako prvního z myslitelů, když ve spisu $O$ nebi přechází k tématu zdůvodnění stability Země. V jeho očích ovšem Xenofanés daný problém vůbec neřešil: „Proto ně-

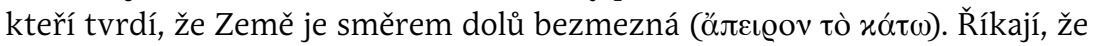

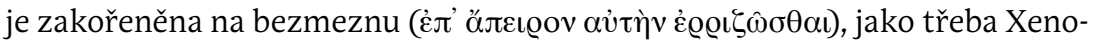
fanés z Kolofónu, aby si ušetřili práci s hledáním přičiny. Za to je pohanil už Empedoklés, a to těmito slovy: ,Pokud by hlubina Země a bohatý aithér byly

21 Aristotelés, De caelo II,13,294b13.

22 Pseudo-Plútarchos, Stromata (dále jen: Strom.) 3 = DK 13 A 6.

23 Hippolytos, Refutatio omnium haeresium (dále jen: Ref.) I,7,4 Marcovich = DK 13 A 7.

24 Áetios, Plac. III,10,3 Diels-Kranz = DK 13 A 20. 


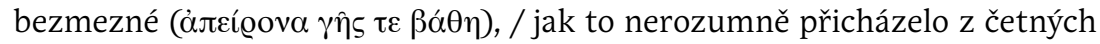
jazyků / a plynulo $\mathrm{z}$ mnoha úst, když věděli málo $\mathrm{z}$ veškerenstva.““25

Můžeme si všimnout, že Xenofanés je uváděn spíše jako reprezentant celé skupiny myslitelů, pro něž měla být Země směrem dolů bezmeznou. Podle Aristotela se tak ale vyhnuli řešení problému její stability. Pokud přitom Sim-

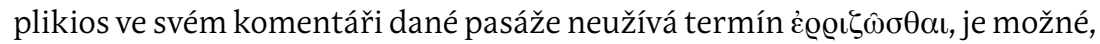
že v Aristotelově textu původně také nefiguroval ${ }^{26}$ : „Protože jsem nenalezl Xenofanovy verše na toto téma, nevím, zda říká, že část Země, která směřuje dolů, je bezmezná, a že z toho důvodu zůstává v klidu, nebo zda místo a aithér pod Zemí jsou bezmezné, a proto Země padá do nekonečna a zdá se být v klidu. Nebot Aristotelés to neobjasn̆uje a ani Empedokleova slova to jasně nevymezují, protože ,hlubina Země může také znamenat i to, do čeho sestupuje. ${ }^{27}$

Simplikios převzal Aristotelův názor, že se Xenofanova koncepce týkala problému nehybnosti Země. Neskrývá však rozpaky nad jejím správným výkladem z důvodu nedostupnosti původního pramene. Do obdobného kontextu pak zasadil jeden z Xenofanových zlomků i Achilleus Tatios: „Xenofanés se nedomníval, že je Země zavěšena, ale spíše, že dosahuje bezmezně

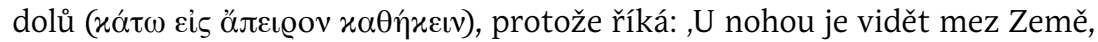
dosahující sem nahoru, stýká se zde vzduchem, zatímco dolní mez ubíhá

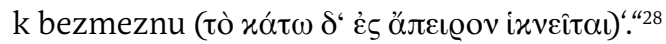

Pokud Xenofanův zlomek podporuje Aristotelovu referenci užitím slova

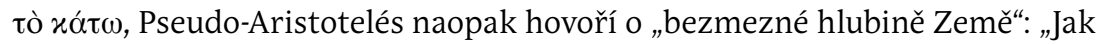

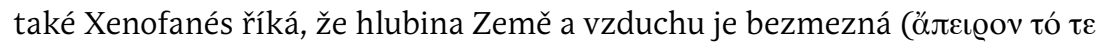

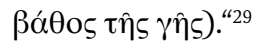

Ačkoli je spolehlivost textu $M X G$ v případě Xenofana problematická, viděli jsme, že i Empedoklés hovoří o „hlubině Země“, $\gamma \eta \hat{\varsigma} \varsigma \beta \alpha a ́ \theta \eta$. Čelíme tak pro-

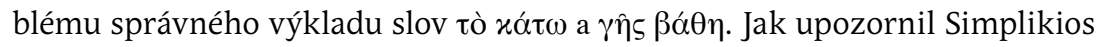
ve svém komentáři, není totiž vůbec zřejmé, zda vyjadřují bezmeznou rozlohu Země, nebo se naopak týkají bezmezného prostoru pod Zemí, do něhož by mohla Země padat. ${ }^{30}$

25 Aristotelés, De caelo II,13,294a21 = DK 21 A 47.

26 Srov. Couprie, D. L., When the Earth Was Flat. Studies in Ancient Greek and Chinese Cosmology. Cham, Springer 2018, s. 133; Simplicius, On Aristotle, On the Heavens 2.10-14. Přel. I. Mueller. London, Gerald Duckworth 2005, s. 115, pozn. č. 295.

27 Simplikios, In Aristotelis De caelo commentaria (dále jen: In Arist. De caelo) 522,7 = DK 21 A 47. Upravil autor.

28 Achilleus Tatios, Isagoge 4, p. 34,11 Maass = DK 21 B 28.

29 Pseudo-Aristotelés, De Melisso, Xenophane, Gorgia 976a32 = DK 30 A 5. Přeložil autor.

30 Srov. Couprie, D. L., When the Earth Was Flat. Studies in Ancient Greek and Chinese Cosmology, c.d., s. 134-135. 
Ke Xenofanově koncepci se navíc opakovaně vyslovuje i Áetios, ačkoli obě jeho pasáže jsou dochovány jen u Pseudo-Plútarcha. Objevuje se v nich přitom opět motiv „zakořenění“, který je doložen u Aristotela: „Xenofanés [ř́iká,

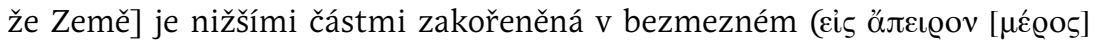

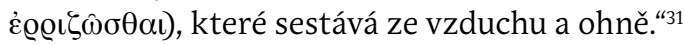

Pokud si Simplikios výše kladl otázku po významu Xenofanových slov, je nyní zřejmé, že podle Áetia se mělo jednat o bezmezný prostor pod Zemí. O zakořenění Země „v bezmeznu“ se navíc vyjadřuje i na jiném místě: „U Xe-

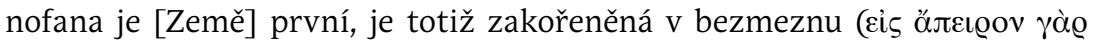

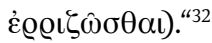

Problém nehybnosti Země potkáváme i u Cicerona, který opět užívá obraz „kořenư“: „Můžeme snad stejným způsobem rozřezat, otevřít a oddělit přirozenosti věcí, abychom viděli, zda je Země hluboko dole upevněna (penitusne defixa sit) a tkví jakoby ve svých kořenech (radicibus suis) [podle Xenofana], nebo zda je ve středu zavěšená? “33

Dochované texty se tak nevyjadřují k př́ípadnému tvaru Xenofanovy Země, ale zaměřují se téměř výhradně na hloubku Země či prostor pod Zemí. Aristotelovi přitom přišla celá koncepce při konfrontaci s otázkou nehybnosti Země v univerzu nedostatečná. Nelze ale než konstatovat, že se v př́padě Xenofanova pojetí nalézáme v situaci, kterou vystihl již Simplikios. Není totiž jasné, zda Xenofanés opravdu hovořil o Zemi rozkládající se bezmezně směrem dolů, nebo naopak o neomezeném prostoru pod Zemí, v němž má své „kořeny“. Pokud však pomineme tento - jakkoli zásadní - rozdíl, nelze nevidět podobnost mezi jednotlivými pasážemi. Na jejím základě se pak lze domnívat, že opravdu tlumočí původní zprávu, jakkoli případně zkomolenou, týkající se prostoru pod Zemí.

Pokud shrneme obraz, který získáváme o iónských archaických koncepcích Země, vidíme, že máme $k$ dispozici pouze obecné či stručné proklamace o jejím tvaru, nebo je Země zmiňována v souvislosti s její nehybností v univerzu. Můžeme ale ještě přihlédnout k samotnému umístění Země v univerzu. Když Aristotelés na začátku 13. kapitoly II. knihy spisu O nebi přistupuje k otázce Země, začíná právě jejím umístěním. Doslova přitom tvrdí, že podle většiny myslitelů, kteří se domnívali, že univerzum je ohraničené, ležela Země v jeho středu. ${ }^{34}$ Áetios pak tradici středového umístění Země odvíjí od Thaléta: „Ti, kdo následují Thaléta, říkají, že Země je uprostřed.“" ${ }^{\text {“35 }}$

31 Áetios, Plac. III,9,4 = DK 21 A 47.

32 Áetios, Plac. III,11,2 = DK 21 A 47.

33 Cicero, Academica priora II,39,122 = DK 21 A 47.

34 Aristotelés, De caelo II,13,293a18-23.

35 Áetios, Plac. III,11,1 Diels = DK 11 A 15. 
Pokud byla Země situována ve středu univerza, přičemž se pod ní zároveň nalézala voda, vzduch, či prostor, v němž měla Země „kořenit“, je evidentní, že byla pokládána za konkrétní hmotné těleso v prostoru univerza. Naskýtá se tak otázka po uspořádání celého světa, jehož byla Země takto součástí.

\section{Uspořádání světa}

V iónských archaických kosmologiích byl se Zemí úzce spojován již vznik nebeských těles, který byl obvykle líčen ve smyslu zapálení výparů vlhkosti Země a moře. Ačkoli neexistoval jednotný popis nebeských těles, kdy je např́íklad Hérakleitos připodobňoval k nádobám, v nichž hoří oheň, nebo je Xenofanés pokládal za vznícená oblaka, jejich sepětí se Zemí bylo nepochybné. ${ }^{36}$ Země navíc nebyla jen místem iniciace vypařování vlhkosti, ale nebeská tělesa na ni zůstávala trvale závislá. S vlhkostí Země totiž souvisel i jejich pohyb, nebot' se za vlhkostí pohybovala doslova jako za „potravou“. ${ }^{37}$ A pokud se vyživovala z vlhkosti Země a moře, obíhala pouze nad povrchem Země. Ačkoli máme explicitní doklady o oběhu nebeských těles výhradně nad Zemí jen v př́padě Anaximena, Aristotelés jej zároveň přisuzuje „četným dávným meteorologům“. ${ }^{38}$ Charakteristické meteorologické pozadí kosmologie následně vedlo Daniela W. Grahama k tomu, že kosmologie 6. století př. Kr. obecně označil za „meteorologický model“, přičemž oběh nebeských těles nad Zemí zahrnul mezi jeden z jejích typických motivů. ${ }^{39}$

Navážeme-li na D. W. Grahama a připustíme, že se v koncepcích iónských archaických myslitelů přes dílčí odlišnosti uplatňuje jedno společné - meteorologické - schéma výkladu, lze se ptát, z čeho samo původně vycházelo. Je přitom možné se domnívat, že určující byla právě koncepce Země. Pokud totiž nebeská tělesa vznikala z výparů Země a moře, přičemž obíhala jen nad zemským povrchem, veškeré dění v univerzu se odehrávalo pouze nad Zemí. A jak jsme rozvedli na jiném místě, z těchto skutečností lze usuzovat, že iónské archaické kosmologie nepředpokládaly žádný volný prostor, který by se pod Zemí prostíral. Ačkoli Země nebyla vnímána pouze jako obyvatelná plocha, ale byla pokládána za „těleso“, které má kromě povrchu i svůj vnitřek a hloubku, celé podzemí - včetně jeskyní a průrev, jimiž lze sestupovat do nitra Země - se rozkládalo právě jen v ní samé. Prostor pod povrchem Země tak byl tvořen pouze její masou. Země zde proto sehrávala roli dolní

36 Např. Áetios, Plac. II,20,3 = DK 21 A 40; DL IX,9 = DK 22 A 1; Hippolytos, Ref. 1,7,4-5 Marcovich = DK 13 A 7.

37 Aristotelés, Meteor. II,2,354b33 = DK 22 A 11.

38 Aristotelés, Meteor. II,1,354a28 = DK 13 A 14.

39 Srov. Graham, D. W., Science Before Socrates. Parmenides, Anaxagoras, and the New Astronomy, c.d., s. 78-84. 
části celého univerza. Nad ní se dále prostíralo nebe, přičemž univerzem byla míněna jen oblast mezi Zemí a nebem. ${ }^{40}$

Patrně nejlépe je v tomto smyslu situace zachycena u Xenofana. Lze soudit, že zmínky o bezmeznosti Země vyjadřují právě tuto skutečnost. Všechny pasáže, které opakují zprávu, že Země sahá do bezmezna nebo v něm koření, ve skutečnosti reflektují stále stejný fakt: pod námi je prostě jen Země a zase jen Země. Její rozsah sahá za naši běžnou zkušenost a představivost. ${ }^{41}$

$Z$ toho důvodu nemohla být Země ani dokola obklopena vzduchem: „[Xenofanés] tvrdí, že Země je bezmezná, že vzduchem nejsou obklopeny všechny její díly. ${ }^{{ }^{4} 2}$

Pokud Hippolytos u Xenofana poukazuje k tomu, že Země nebyla obklopena nebem, lze usoudit, že se pro něho nalézalo pouze nad ní: „Země je bezmezná a není obklopena ani vzduchem, ani nebem. ${ }^{443}$

Jak upozornil Detlev Fehling, Země tak byla pokládána za centrální vztažnou plochu veškerého prostoru. Vymezovala spodní dimenzi a rozsah univerza, které sama zakládala. Zmínkám o tom, že se Země nalézala ve středu, proto nemůžeme rozumět v běžném smyslu geocentrismu, jak je obvyklé. Země totiž nebyla umístěna v prostoru univerza, ale sama tento prostor vytvářela. $Z$ toho důvodu měla být podle Xenofana doslova "první“.44

Vlastní vznik univerza a počátek všech dějů, k nimž v něm dochází, se proto odvíjel právě od Země. Není tedy překvapivé, zaznamenává-li Pseudo-Plútarchos u Anaximena, že „nejprve vznikla velmi plochá Země““45 Jedná se o akcent na prvotní vznik, kterým je zároveň vyjádřena ústřední role Země ve strukturaci univerza. Až po jejím zrodu mohla následně vzniknout i nebeská tělesa. Pokud Země vymezovala spodní rozsah univerza, je nyní zřejmé, proč byla nebeská tělesa pojata jako výpary Země a moře. Proto měla blízko k oblakům, jejichž doménou je oblast nebe, a obíhala pouze nad Zemí. Právě z koncepce Země se dále odvinul meteorologický charakter celé kosmologie.

Jestliže Země představovala centrální plochu prostoru, všechna tělesa musela padat jen k jejímu povrchu. Problém pádu samotné Země tak ještě nenastal. V tomto kontextu je pozoruhodné, že Aristotelés ve spisu O nebi upo-

40 Srov. Kočandrle, R., Prostor pod Zemí v iónských archaických kosmologiích, c.d.

41 Srov. Kirk, G. S. - Raven, J. E. - Schofield, M., Předsókratovští filosofové. Kritické dějiny s vybranými texty. Přel. F. Karfík - P. Kolev - T. Vítek. Praha, Oikúmené 2004, s. 117-118; Lesher, J. H., Xenophanes of Colophon: Fragments. Toronto-Buffalo-London, University of Toronto Press 1992, s. 129-131.

42 Pseudo-Plútarchos, Strom. 4 = DK 21 A 32.

43 Hippolytos, Ref. I,14,3 Marcovich = DK 21 A 33.

44 Srov. Fehling, D., Das Problem der Geschichte des griechischen Weltmodells vor Aristoteles. Rheinisches Museum, 128, 1985, Nr. 3-4, s. 212.

45 Pseudo-Plútarchos, Strom. 3 = DK 13 A 6. 
zorňuje, že se „někteří“ myslitelé domnívali, že „Země je směrem dolů bezmezná", a vůbec tak neřešili problém její nehybnosti. Ačkoli zmiňuje jménem pouze Xenofana, lze soudit, že se ve skutečnosti jednalo i o ostatní zástupce iónské archaické kosmologické tradice - třebaže právě je nemá Aristotelés na mysli. Můžeme proto navrhnout ke zvážení, že proslulé umístění Země na vodě u Thaléta je pouhým anachronismem. Podobně by byl Anaximenés pouze mylně spojen s pozdními mysliteli, u nichž byl problém nehybnosti Země již nastolen. Aristotelés přitom mohl zvolit dané „opory“ Země vždy

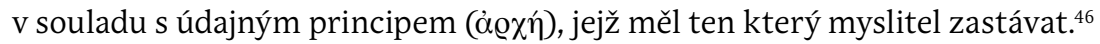

Důsledkem uvedených skutečností je ale zásadní poznatek, že v iónských archaických kosmologiích Země nepředstavovala konkrétní těleso, které by bylo umístěné v okolním prostoru univerza. Nebyla ještě vnímána jako kosmické těleso. Od ní se naopak rozbíhal vlastní prostor univerza, které tak spoluvytvářela. Zmínky u Anaximena, že Země byla plochá, představují jen akcent na její povrch, přičemž odhlížejí od celé zemské masy „ubíhající k bezmeznu“. Pokud koncepce Země jako kosmického tělesa vyžaduje i určité pojetí okolního univerza, nemusí být náhodné, že v př́ípadě iónských archaických kosmologií nemáme žádný tvar univerza ani naznačen.

\section{Krátký exkurz k italské větvi filosofie}

V kosmologiích 5. století př. Kr. se však náhle setkáváme s naprosto jinými poměry, než jaké jsme dosud viděli. Ačkoli Anaxagorás a atomisté stále zastávali pojetí ploché Země, měla se zjevně nalézat v prostoru univerza, přičemž nebeská tělesa obíhala i pod jejím povrchem. ${ }^{47}$ Země tak již představovala konkrétní těleso. Samotná nebeská tělesa byla nyní popisována obvykle jako rozžhavené kusy kovu či kameny. Daniel W. Graham proto v dané souvislosti hovoří o tzv. „lithickém“ modelu, který demonstruje odlišnost kosmologií 5. století př. Kr. a který měl začít Anaxagorou. ${ }^{48}$

Můžeme se přitom domnívat, že tato zásadní změna byla důsledkem nové koncepce prostoru, kdy univerzum již nebylo pojímáno pouze jako prostírající se mezi plochou Zemí a nebem. Jak jsme rozvedli na jiném místě, na základě dochovaných zpráv je možné soudit, že to byl konceptuální náhled sférického univerza, co umožnilo nově formulovat podmínky panující v univerzu. S tím byla zároveň spjata i koncepce kulové Země, která představovala nové spekulativní uchopení jejího konkrétního geometrického tvaru.

46 Srov. Fehling, D., Das Problem der Geschichte des griechischen Weltmodells vor Aristoteles, c.d., s. 213-215.

47 Např. Hippolytos, Ref. I,8,8 Marcovich = DK 59 A 42.

48 Srov. Graham, D. W., Science Before Socrates. Parmenides, Anaxagoras, and the New Astronomy, c.d., s. 134-136. 
Až právě v tomto pojetí se Země mohla stát daným tělesem v prostoru a být zároveň v „něčem“ umístěna. Prostor přitom získal trojrozměrnost. V iónské archaické kosmologii - především u Anaximena - se naopak setkáváme s popisy plochých nebeských těles, které evokují pouze dvojrozměrnost těles a prostoru. ${ }^{49}$

Jak přitom poukázal Dmitri Panchenko, Anaxagorás zjevně argumentoval proti koncepci kulové Země, která tak musela být v jeho době již známa. ${ }^{50}$ Některé doxografické zmínky o ní bychom proto měli brát vážně. Ačkoli jsme kulovou Zemi výše u Thaléta odmítli jako anachronismus, lze soudit, že s největší pravděpodobností byla formulována v italské větvi filosofie, kterou od iónské odlišuje Diogenés Laertios. ${ }^{51} \mathrm{U}$ italských myslitelů totiž máme hned několik vodítek, která poukazují k tomu, že právě zde došlo k této významné změně v kosmologii.

Sférickou podobu univerza a zároveň Země dokládá Diogenés Laertios

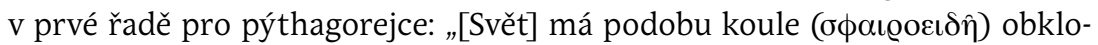

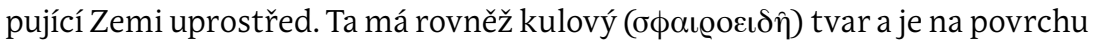
obydlená." ${ }^{52}$

Textové doklady pýthagorejců jsou bohužel veskrze problematické a částečnou rekonstrukci pýthagorejské kosmologie umožňují až zprávy o Filoláovi, který však působil ve druhé polovině 5 . století př. Kr. Navíc se v jeho kosmologii nalézá ve středu světa oheň, kolem něhož obíhá spolu s ostatními tělesy i Země. ${ }^{53}$ Pokud budeme geocentrické uspořádání pokládat za výchozí předlohu, která vycházela z původního výměru Země jako „základny“ univerza, jednalo by se tak o komplikovaný model.

Můžeme však upřít pozornost ještě $\mathrm{k}$ jinému představiteli italské větve filosofie: Parmenidovi. Ačkoli je jeho kosmologie podobně temná, nalézáme zde náznaky koncepce sférického univerza s kulovou Zemí v jeho středu.

Když Diogenés Laertios pojednává o Pýthagorovi, popisuje tvar jeho Země

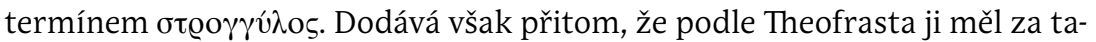

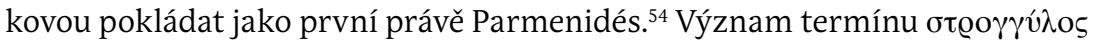
ovšem kolísá mezi „okrouhlý“ a „kulový“. Země tak mohla u obou myslitelů představovat plochý okrouhlý disk. Protože by však šlo o tvar zastávaný již dřive, lze se domnívat, že Diogenés má na mysli právě kulovou Zemi. V tomto

49 Srov. Kočandrle, R., Hledání původu koncepce rovnovážného umístění Země. Aither, 2017, č. 17, s. 4-31; týž, Prostor pod Zemí v iónských archaických kosmologiích, c.d.

50 Srov. Panchenko, D., Anaxagoras' Argument against the Sphericity of the Earth, Hyperboreus, 3, 1997, s. $175-178$.

51 DL I,13 Marcovich.

52 DL VIII,25 Marcovich = DK 58 B 1a.

53 Áetios, Plac. II,7,7 = DK 44 A 16; Aristotelés, De caelo II,13,293a18 = DK 58 B 37.

54 DL VIII,48 Marcovich = DK 28 A 44. 
smyslu ji ostatně Parmenidovi připisuje i následně55: „Parmenidés první pro-

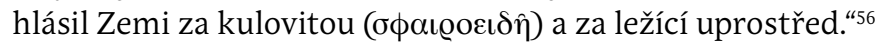

Diogenovy reference však nelze dosvědčit z jiného zdroje. Přesto je možné znalost sférického pojetí u Parmenida doložit i na jiných místech. Áetios totiž Parmenidovi přikládá zdůvodnění nehybného umístění Země v univerzu na základě souměrnosti, nebot' je „ode všeho stejně vzdálena“. ${ }^{57}$ Ačkoli daný argument připisuje Aristotelés Anaximandrovi, uvádí jej rovněž Platón, který zároveň ukazuje, že jeho platnost se zakládá na shodném - sférickém tvaru Země i obklopujícího univerza, které přitom u Anaximandra nenalézáme. ${ }^{58}$ Pokud Sókratés doslova říká, že se o daném pojetí dověděl od „kohosi“,59 mohl jím být právě Parmenidés.

Podporuje-li uvedený argument domněnku, že Parmenidés předpokládal kulovou Zemi, poukazuje zároveň na shodný tvar i v případě univerza. Pro sférický tvar univerza by navíc mohlo hovořit doslovné kosmologické čtení Parmenidovy básně, v níž připodobňuje pravé jsoucno ke kouli. ${ }^{60}$ Simplikios ${ }^{61} \mathrm{v}$ tomto smyslu zachovává Eudémovu poznámku, že Parmenidovo jsoucno bylo interpretováno právě v kosmologickém významu jako „nebe“ (oủoavós). ${ }^{62}$

Pojetí světa, ve kterém sféra nebe tvoří prostor celého univerza, v němž se spolu s kulovou Zemí v jeho středu nalézají ostatní nebeská tělesa, se následně uplatnilo u Platóna a především pak Aristotela. Právě pýthagorejci a Parmenidés tvoří dvě zásadní linie, které se nejvýznamněji otiskly do Platónova učení. Zatímco v dialogu Tímaios ${ }^{63}$ nalézáme spíše vzorové užití celé koncepce, Aristotelés pro ně již přímo argumentuje v rámci své fyziky. Aristotelés,

55 Srov. Graham, D., The Texts of Early Greek Philosophy. The Complete Fragments and Selected Testimonies of the Major Presocratics. Vol. I. Cambridge, Cambridge University Press 2010, s. 241; Kahn, Ch. H., Anaximander and the Origins of Greek Cosmology. New York, Columbia University Press 1960, s. 115.

56 DL IX,21 Marcovich = DK 28 A 1.

57 Áetios, Plac. III,15,7 = DK 28 A 44.

58 Platón, Phaedo (dále jen: Phd.) 108e-109a.

59 Platón, Phd. 108c.

60 Simplikios, In Arist. Phys. 146,15 = DK 28 B 8,42-49.

61 Simplikios, In Arist. Phys. 133,21-29; 142,28-143,8 = Eudémos, fr. 44, 45 Wehrli = A. H. Coxon, The Fragments of Parmenides. Las Vegas-Zürich-Athens, Parmenides Publishing 2009, Eudémos, test. 37, 38.

62 Srov. Fehling, D., Das Problem der Geschichte des griechischen Weltmodells vor Aristoteles, c.d., s. 226-227; Furley, D., The Greek Cosmologists.Vol. I: The Formation of the Atomic Theory and its Earliest Critics. Cambridge, Cambridge University Press 1987, s. 53-57; Graham, D. W., Science Before Socrates. Parmenides, Anaxagoras, and the New Astronomy, c.d., s. 90-91; s. 96; s. 106-107, pozn. č. 44; Hladký, V., Transmigrating Soul Between the Presocratics and Plato. Aither, 2018, International Issue No. 5, s. 33, pozn. č. 62.

63 Platón, Timaeus (dále jen: Tim.) 33b-c; 62d-63a. 
který tak již vycházel z trojrozměrnosti prostoru, mohl jeho předpoklady zpětně mylně připsat i myslitelům působícím před Parmenidem.

Přiznáme-li Parmenidovi prvenství ve formulaci koncepce kulové Země nalézající se ve středu sférického univerza, mohli bychom ho pokládat za objevitele prostoru s hloubkou univerza. Zároveň bychom ho mohli označit za toho, kdo první spekulativně nahlédl Zemi jako kosmické těleso. Ačkoli byla Země umístěna ve středu světa a neobíhala kolem něj jako ostatní nebeská tělesa, byla jako taková pokládána za konkrétní těleso umístěné v obklopujícím prostoru univerza. Přesto se domníváme, že tento primát Parmenidovi ve skutečnosti nenáleží. Lze jej totiž přiřknout jinému mysliteli, jemuž jsme se doposud ve výkladu vyhýbali. Tím je Anaximandros.

\section{Anaximandrova Země}

Viděli jsme, že popisy Země u iónských archaických myslitelů jsou velmi sporé. V zásadě pocházejí z kontextu údajného nehybného umístění Země v univerzu. Naprosto z nich ovšem vybočují texty, které informují o Anaximandrově pojetí. Nejen, že je jich větší množství, ale jsou navíc konkrétní a popisné. Obecně přitom pocházejí ze dvou hlavních okruhů. Jednak opět líčí důvod nehybného postavení Země, nadto ovšem přibližují i její tvar.

Zatímco ostatní autoři u Anaximena většinou pouze opakují informaci o plochém tvaru Země, Áetios přináší i analogii ke stolu. V případě Anaximandra pak Zemi přirovnává ke kamennému sloupu: „Anaximandros [ř́íká],

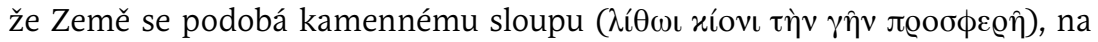
jedné z jeho ploch †...†." ${ }^{46}$

Edice Diels-Kranz zařadila zmínku o kamenném sloupu mezi Anaximandrovy zlomky. Hippolytos text navíc dále rozvíjí, přičemž zachovává i celý

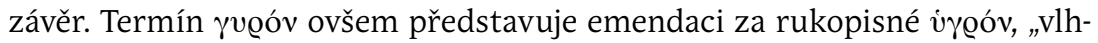
ký“:65 „Její podoba je okrouhlá, oblá, podobá se kamennému sloupu ( $\gamma$ voóv,

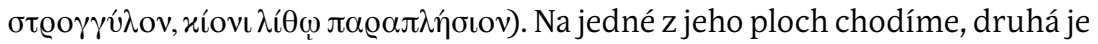

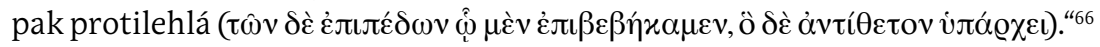

Pseudo-Plútarchos nenásleduje motiv celého sloupu, ale připodobňuje Zemi k válci a uvádí i jeho poměry: „Řekl také, že Země je podoby válcové

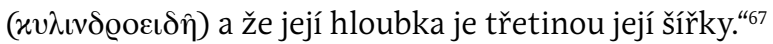

Ačkoli by „válcová podoba“ mohla reprezentovat celý sloup, představené poměry odkazují spíše k nízkému válci. Jsou tak jedním z klíčových důvo-

64 Áetios, Plac. III,10,2 = DK 12 A 25 = DK 12 B 5.

65 Srov. DK, s. 84.

66 Hippolytos, Ref. I,6,3 Marcovich = DK 12 A 11.

67 Pseudo-Plútarchos, Strom. 2 = DK 12 A 10. 
dů, proč je Anaximandrova Země obvykle vykládána nikoli ve smyslu celého sloupu, nýbrž pouze jeho části - bubnu. Právě z jednotlivých bubnů byly totiž sloupy sestavovány. Obývané oblasti Země by přitom odpovídala horní plochá strana bubnu - horní podstava válce. ${ }^{68}$

Jak jsme výše viděli, Aristotelés ve spisu $O$ nebi rozlišuje u svých předchůdců vedle kulové i plochou Zemi, přičemž konkrétně vymezuje její tvar

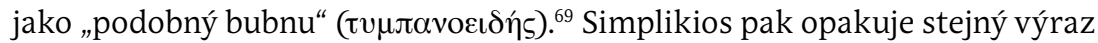
ve svém komentáři. ${ }^{70}$ Míněna ale může být především Země pozdních koncepcí Anaxagory a atomistů. Pokud by z nich následně vycházela i PseudoPlútarchova zpráva, u Anaximandra by mohl být naopak původní motiv celého sloupu.

Pro pravost přirovnání Země ke kamennému sloupu hovoří zejména to, že analogie bývají pokládány za autentický způsob iónského vyjadřování. Navíc nalézáme oporu u Ptolemaia, který argumentuje proti koncepci válcovité Země, jejíž obývaná oblast by ovšem odpovídala oblé straně válce. ${ }^{71}$ Ptolemaiova kritika jasně ukazuje, že opravdu existovala koncepce, v níž byla Země za válec pokládána, přičemž obývaná část neodpovídala jedné z plochých podstav válce, ale jeho oblému plášti. Podobně Dmitri Panchenko poukázal na to, že válcovitá Země zakřivená podél severo-jižní osy, s plochými podstavami orientovanými na východ, respektive západ, by umožnila lepší vysvětlení různých nebeských jevů. Zmínky Hippolyta a Áetia o dvou plo-

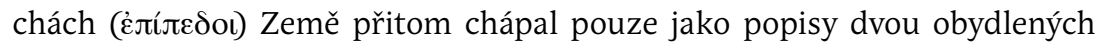
částí Země oddělených obklopující vodou. ${ }^{72}$

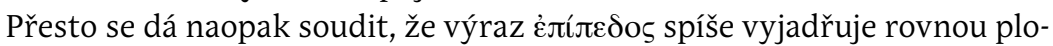
chu či povrch, a nikoli části území jako takové.73 Reference o dvou plochách Země, kdy na jedné z nich žijeme, zatímco „druhá je protilehlá“, spolu s Pseudo-Plútarchem představenými poměry Země tak evokují, jak jsme uvedli, tvar Země jako nízkého válce s protilehlou horní a spodní plochou podstavou. $^{74}$

68 Srov. Couprie, D. L., Heaven and Earth in Ancient Greek Cosmology. From Thales to Heraclides Ponticus, c.d., s. 104-106.

69 Aristotelés, De caelo, II,13,293b34-294a1.

70 Simplikios, In Arist. De caelo 520,28 = DK 59 A 88.

71 Ptolemaios, Almagest I,4.

72 Srov. Panchenko, D., Anaximandros of Miletos. In: Gehrke, H.-J. - Maier, F., (Hrsg.), Die Fragmente der Griechischen Historiker Part V, 2013, online. Dostupné na: <http://dx.doi.org/10.1163/18735363 jcv_a2103>; [cit. 30. 8. 2020].

73 Liddell, H. G. - Scott, R., A Greek-English Lexicon. With a Revised Supplement: Jones, H. S. - Mc-

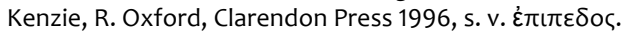

74 Srov. Couprie, D. L., Heaven and Earth in Ancient Greek Cosmology. From Thales to Heraclides Ponticus, c.d., s. 105. 
Do zvažovaných tvarů Země se navíc vřazuje i Diogenés Laertios jednoznačným tvrzením, podle něhož byla Země kulová: „Uprostřed leží Země, která zaujímá střed a má tvar koule.“75

Jedná se ale pouze o anachronismus - Detlev Fehling soudil, že pochází $z$ dále uváděného argumentu o nehybnosti Země, za nímž je právě předpoklad kulové Země. Mohl se ale zakládat rovněž na dvojznačném významu

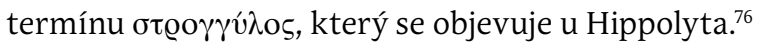

Ačkoli v otázce Anaximandrovy Země nelze vznést definitivní slovo, je zjevné, že její tvar byl obecně válcovitý. Pokud opravdu představovala pouze buben celého sloupu, povrch plochy, na „níž žijeme“, byl nejspíše pokládán

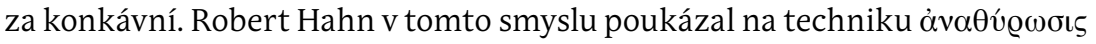
užívanou při spojování jednotlivých bubnů do výsledného sloupu. Konkávní

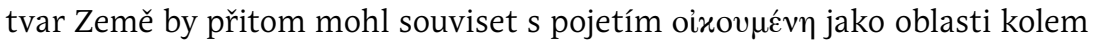
Středozemního moře.77

Kromě tvaru Země Diogenés navíc zmiňuje i její postavení ve středu. Lze se domnívat, že míněn je střed světa. Dále uvidíme, že v daném případě tlumočí umístění Země uprostřed kruhů nebeských těles. O středovém umístění Země se přitom vyjadřuje i lexikon Súda: „První objevil rovnodennost, slunovraty a hodiny i to, že Země leží v úplném středu [světa]."

Zatímco uvedené texty se týkaly tvaru Země či jejího umístění ve středu světa, další skupina textů se již věnuje zdůvodnění její stability. Oproti ostatním Mílétanům, kteři měli údajně předpokládat některou z konkrétních opor Země, je u Anaximandra náhle rozhodující pouze její umístění, díky němuž se nalézá v rovnováze. Nejstarším ze zachovávajících autorů je přitom Aristotelés: „Jsou však tací, kteří tvrdí, že Země setrvává v klidu díky souměrnosti; jako ze starých myslitelů Anaximandros. Nic, co je usazeno ve středu a je stejně vzdálené od krajů, se nemůže pohybovat spíše nahoru, dolů nebo do stran. Současně je nemožné, aby se to pohybovalo v protikladných směrech, takže nutně setrvává v klidu."79

75 DL II,1-2 = DK 12 A 1 .

76 Srov. Fehling, D., Materie und Weltbau in der Zeit der frühen Vorsokratiker. Wirklichkeit und Tradition. Innsbruck, Verlag des Instituts für Sprachwissenschaft der Universität Innsbruck 1994, s. 146; Kahn, Ch. H., Anaximander and the Origins of Greek Cosmology, c.d., s. 56.

77 Srov. Couprie, D. L., Heaven and Earth in Ancient Greek Cosmology. From Thales to Heraclides Ponticus, c.d., s. 105-106; Hahn, R., Anaximander and the Architects. The Contributions of Egyptian and Greek Architectural Technologies to the Origins of Greek Philosophy. Albany, State University of New York Press 2001, s. 194-197; Kahn, Ch. H., Anaximander and the Origins of Greek Cosmology, c.d., s. 56; s. 81 , pozn. č. 3.

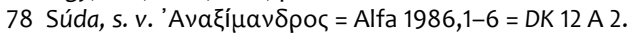

79 Aristotelés, De caelo II,13,295b10 = DK 12 A 26. 
Hippolytos se sice o středovém umístění Země nezmiňuje, hovoří ale nově o jejím „vznášeni““: „Země se volně vznáší, aniž by byla něčím držena. Setrvává tak, nebot' její vzdálenost je od všeho stejná."80

Středovou pozici Země naopak zachovává Theón ze Smyrny, který spolu se „Vznášením“ akcentuje navíc i pohyb Země: „Anaximandros říká, že Země se vznáší a že se pohybuje kolem středu světa." ${ }^{\text {"A1 }}$

Simplikios pak ve svém komentáři k Aristotelově pasáži přidává dalšího činitele přítomného v celé soustavě - vzduch: „Anaximandros se pak domníval, že Země zůstává nahoře, a to jak kvůli podpírajícímu vzduchu, tak rovnováze a souměrnosti." ${ }^{\text {"2 }}$

Jak jsme uvedli, přehlédneme-li popisy Anaximandrovy Země, vidíme, že se významným způsobem odlišují od těch, s nimiž jsme se setkali u ostatních iónských myslitelů. U nich máme k dispozici spíše obecné deskripce, které jen v př́ípadě Anaximena více přibližují tvar Země. U Anaximandra je ale Země konkrétně popisována. A to jak prostřednictvím analogie ke kamennému sloupu, tak přiblížením jejího tvaru jako válce s konkrétními poměry stran. Patrně nejzásadnější je ale Hippolytova zmínka, kterou podporuje Áetios, o plochách Země, po jedné z nichž „chodíme“, zatímco druhá je „protilehlá“. Lze přitom soudit, že význam této poznámky nebyl dříve dostatečně doceněn, nebot ji badatelé obvykle přecházeli či spojovali s případnými protinožci. ${ }^{83}$ Ve skutečnosti si ale musíme uvědomit, že se jedná o popisy tělesa. Je-li Země líčena jako sloup - válec, přičemž jsou uváděny její dvě protilehlé plochy, jde o konkrétní těleso. $V$ případě Anaximandra tak Země nesehrává roli spodní dimenze celého univerza. Zatímco u Anaximena bude analogie Země ke stolu vedena pouze akcentem na jeho plochou desku, u Anaximandra je Země pojata jako skutečný objekt, který má své rozměry a je v něčem umístěn. K tomu poukazuje i skupina textů, podle nichž Země sloužila jako měřítko pro stanovení velikostí nebeských těles. ${ }^{84}$

O prostoru kolem Země se přitom zmiňují pasáže přibližující stabilitu Země v univerzu. Pokud Aristotelés tvrdí, že se Země nalézá v klidu díky svému souměrnému umístění, akcentuje umístění tělesa Země v okolním prostředí. Podobný prostorový význam mají i zmínky o jejím „vznášení“. Ačkoli nejsme o tvaru univerza nijak informováni, sama Země se nalézá uprostřed kruhů nebeských těles, které okolní prostředí vytvářejí.

80 Hippolytos, Ref. 1,6,3 Marcovich = DK 12 A 11.

81 Theón ze Smyrny, De util. mat. 198,18 = DK 12 A 26.

82 Simplikios, In Arist. De caelo 532,13-14.

83 Srov. Gregory, A., Anaximander. A Re-assessment. London-New York, Bloomsbury 2016, s. 139; Kahn, Ch. H., Anaximander and the Origins of Greek Cosmology, c.d., s. 56; s. 84-85.

84 Áetios, Plac. II,20,1 Mansfeld-Runia = DK 12 A 21; II,21,1 Mansfeld-Runia = DK 12 A 21; II,25,1 Mansfeld-Runia = DK 12 A 22; DL II,1 Marcovich = DK 12 A 1; Hippolytos, Ref. I,6,5 Marcovich = DK 12 A 11. 
Nebeská tělesa totiž podle Anaximandra nevznikají až později jako výpary ze Země a moře, ale vznikla naopak již v prvních fázích kosmogonie. Doslova se přitom jedná o pozůstatky planoucí sféry, která v raných fázích vzniku světa obklopovala Zemi: „Říká pak, že to, co rodí teplo a chlad, se při vzniku tohoto světa odloučilo z toho, co trvá, a z něj vyrostla kolem vzduchu, který je okolo Země, jakási planoucí sféra, jako kůra kolem stromu. Když se tato sféra odlámala a uzavřela do jakýchsi kruhů, ustavilo se Slunce, Měsíc a hvězdy." ${ }^{\text {"s }}$

Nebeská tělesa se vytvořila v podobě ohnivých kruhů, které následně obklopil vzduch mlžné konzistence. Jejich oheň vidíme na nebi skrze průduch na mlžném obalu celého kruhu: „Nebeská tělesa jsou jako kruh ohně, odloučila se z ohně, který byl v kosmu, a obklopil je vzduch. Jsou však průduchy, jakožto jakési póry na způsob píštaly, kterými se nebeská tělesa ukazují. Proto také uzavřením těchto průduchů dochází k zatměním." ${ }^{86}$

Pokud je v Anaximandrově pojetí vznik nebeských těles významně odlišný od jejich vzniku u ostatních iónských archaických myslitelů - přičemž navíc ani nepředstavují pouhé zapálené výpary, ale konkrétní kruhové objekty -, je dalším zásadním rozdílem skutečnost, že při svém oběhu procházejí i pod Zemí. Ačkoli nás o dané skutečnosti neinformuje žádný z textů, oběh nebeských těles pod Zemí nepřímo dokladuje Áetios, když zmiňuje sklon kruhu Slunce a Měsíce. ${ }^{87}$ Má-li se Země nalézat uprostřed kruhů nebeských těles, které jsou skloněny, musejí procházet pod jejím povrchem. Pod Zemí a kolem ní se tak rozkládá prostor, kterým mohou tělesa obíhat. Proto jsou popisována jako konkrétní objekty, přičemž může být poprvé zmíněna i spodní strana Země, která rovněž představuje těleso. Celé univerzum tím získává trojrozměrnost. Spolu s Dirkem L. Coupriem tak lze Anaximandra považovat za „objevitele prostoru“.88

Je přitom signifikantní, že jediná dostupná pasáž přibližující proces kosmogonie uvádí Zemi nalézající se ve vzduchu, který je doslova „okolo“ ní. Země tak byla očividně již od počátku pojata jako těleso umístěné v prostoru. V ustaveném univerzu byla následně situována uprostřed kruhů nebeských těles. Ačkoli je Anaximandrova koncepce důsledně geocentrická, pokud byla Země pokládána za konkrétní těleso $\mathrm{v}$ prostoru univerza, byla z pohledu kosmologie poprvé nahlédnuta jako kosmické těleso.

Odtud zřejmě plynul i důvod, proč Aristotelés spojil Anaximandra s argumentem o rovnováze Země, který pocházel až od Parmenida. Mohl mít totiž

85 Pseudo-Plútarchos, Strom. 2 = DK 12 A 10.

86 Hipppolytos, Ref. I,6,4 Marcovich = DK 12 A 11.

87 Áetios, Plac. II,25,1 Mansfeld-Runia = DK 12 A 22.

88 Srov. Couprie, D. L., Heaven and Earth in Ancient Greek Cosmology. From Thales to Heraclides Ponticus, c.d., s. 99. 
k dispozici zprávy referující o Mílétanově dobově unikátní koncepci symetrického univerza s oběhy nebeských těles pod Zemí. Vzhledem k výrazné roli vzduchu se přitom lze domnívat, že vzduch vyplňoval celé univerzum a nalézal se tak i pod Zemí. Podobné pojetí se přitom dále uplatnilo v nadcházejících iónských kosmologiích 5. století př. Kr. Ve své době však Anaximandrova koncepce nedošla v Iónii bezprostředního pokračování. Anaximandros tak představuje významnou výjimku v iónské archaické kosmologické tradici.

Následně to byl až Parmenidův apriorní intelektuální výkon, jímž byla důsledně nahlédnuta trojrozměrnost prostoru, ovšem v rámci zcela jiného rozvrhu - kulové Země uprostřed sférického univerza.

\section{Závěrem}

Ačkoli současné interpretace obvykle vycházejí z předpokladu, že Země v iónských archaických kosmologiích představovala samostatné kosmické těleso, ve skutečnosti se jedná o anachronismus. Lze se totiž domnívat, že pro hlavní proud iónských archaických kosmologií Země nebyla kosmickým tělesem nalézajícím se v prostředí univerza. Ztělesňovala naopak celou jeho spodní dimenzi, nebot' pod ní nebyl předpokládán žádný volný prostor. Koncepce Země jako kosmického tělesa se objevila až následně v italské větvi filosofie. Na základě dostupných svědectví je možné soudit, že zde Parmenidés předložil vizi kulové Země uprostřed sférického univerza. V tomto pojetí se Země již stala konkrétním tělesem umístěným v okolním prostředí. Ještě předtím to však byl Anaximandros, kdo v rámci iónské archaické kosmologie dokázal jako první tematizovat trojrozměrnost prostoru univerza. A právě Anaximandros také vůbec poprvé pojal Zemi jako kosmické těleso. 


\section{SUMMARY \\ The Earth as a Cosmic Body in Pre-Socratic Cosmology}

Interpretations of the Earth in Ionic archaic cosmologies usually revolve around the idea of it being a flat disc lying on water or air. In them, the Earth is also conceived as a concrete body situated in the space of the universe. However, due to the meteorological nature of Ionic archaic cosmologies, we can presume that in these cosmologies space was not generally assumed to exist under the Earth. The Earth, then, constituted the lower dimension of the universe as a whole and was not therefore considered a cosmic body. A fundamental change did not occur until the cosmology of the Italian branch of philosophy, which conceived of both the Earth and the universe as being in the shape of a sphere - meaning that the Earth became a separate body. If however still earlier reports of Anaximander's Ionic cosmology described a cylindrical Earth located in the middle of the rings of celestial bodies, we might conclude that it was Anaximander who was the first to consider Earth to be a cosmic body.

Keywords: Anaximander, cosmology, meteorology, Parmenides, Earth

\section{ZUSAMMENFASSUNG Die Erde als kosmischer Körper in der vorsokratischen Kosmologie}

Die Interpretationen der Erde in ionischen archaischen Kosmologien arbeiten in der Regel mit der Vorstellung einer flachen auf Wasser oder auf Luft liegenden Scheibe. Die Erde wird dort gleichfalls als konkreter Körper im Raum des Universums aufgefasst. In Anbetracht der meteorologischen Natur ionischer archaischer Kosmologien kann jedoch vermutet werden, dass diese Kosmologien im Allgemeinen keinen Raum unterhalb der Erde voraussetzten. Die Erde stellte somit die untere Dimension des gesamten Universums dar, wobei sie nicht als kosmischer Körper angesehen wurde. Eine grundlegende Änderung fand erst in der Kosmologie des italienischen Zweigs der Philosophie statt, in der die Erde sowie das Universums die Form einer Sphäre hatten dadurch wurde die Erde zu einem selbstständigen Körper. Wenn jedoch noch davor Berichte über die ionische Kosmologie des Anaximandros Beschreibungen einer zylinderförmigen Erde inmitten von Kreisen von Himmelskörpern enthalten, kann daraus geschlossen werden, dass es Anaximandros war, der die Erde als Erster für einen kosmischen Körper hielt.

Schlüsselwörter: Anaximandros, Kosmologie, Meteorologie, Parmenides, Erde 